\title{
Study of microbial contents in different types of potable Water from different area of Ghaziabad
}

Available online at www.ijistweb.com

RESEARCH ARTICLE

Mohit Sharma*, R Sivaperumal

Department of Microbiology, Sri Satya Sai University of Technology \& Medical Sciences, Sehore466001, India.

*Corresponding Author's E-mail: om11agra85@gmail.com

\begin{abstract}
In Ghaziabad district of Uttar Pradesh, groundwater is one of the substantial resources that need great concern as it is consumed by all the sectors of domestic, irrigation and industrial purposes. The present study examined the groundwater quality of the district on the basis of land use types. A total number of 6 sites were identified in the district from residential, industrial and agricultural areas during pre-monsoon (May 2017) season. It shows that, even the source is not protected; water is not contaminated all the time with faecal pathogens at source. Mostly, water has become contaminated at household because of the poor hygiene practice. The faecal pathogens pathway for water contamination is highly susceptible. Water treatment system is necessary to provide potable water for the community. Together with the water quality improvement, personal hygiene enhancement is also mandatory. The community of Chotidanda is not aware of the links between hand hygiene and water quality. Even though people do not take any action to improve the water quality in household level they are positive about protecting the water source and for water quality improvement system in community level.
\end{abstract}

Keywords: Water Analysis, Microbe, Hygiene, Pathogen, E.Coli.

\section{Introduction}

Water is one of the most important and basic natural resources. Among all natural resources, water is the most precious one and life is not possible without water. It is one of the basic needs of the mankind and is vital to all forms of life, which exist in lentic and lotic habitats (1). It is considered as the universal solvent having many chemical constituents dissolved in it, utilizing these in various metabolic activities the aquatic organisms bring about changes in chemical composition of water (2-4).

The microbial contamination of water is often of fecal nature related to humans (water sewage treatment plants, combined sewage overflow (CSO), non-collective sewage systems), domesticated animals (manure spreading, pit stock overflow), or wildlife (5-8). The main origins of microbial contamination of natural aquatic resources are discharges of water treatment plants, decontamination stations, hospitals, industries considered as point sources, etc. Correlation between pathogens concentrations and urban activities is well documented. On the other hand, diffuse sources (slurry, manure, sludge application...) may also be considered. The abundance and importance of pathogens in water depend on factors such as the contamination level, pathogens' persistence in water bodies, biological reservoirs (including aquatic plants and sediments) and the ability of pathogens to be transported. The land use management practices and the size of the watershed also influence the survival of microorganisms. According to George et al., streams flowing through areas partly or fully covered with pastures are more contaminated than those running through forests and cultivated areas (9-10).

In freshwater ecosystems, micro-organisms inhabit the water column as suspended microbes, as sessile microbes in bio-film attached to vegetation and substrate surfaces, or as microbial mats in benthic habitats where microbes are compressed to microbial layers according to their biological activity requirements (11).

The focus of this study will be microbial abundance and activity changes in water column and substrate bio film samples. Tupe et. al. studied on enumeration and distribution of some 
indicators of feacal pollution, entric pathogens and total viable counts along Mula-Mutha river in Pune. Chatterjee and Raziuddin evaluated the magnitude of coliform bacteria in the Nunia river water to assess its sustainability for human use (12). Vincent $\mathrm{N}$ et.al Study of the bacteriological and physicochemical indicators of pollution of surface water, this study investigates the pollution level of surface waters in Zaria, Nigeria. The frequency of contamination of samples with Escherichia coli 157 was only $2.2 \%$. There was a positive correlation between faecal coliform counts with most of the physicochemical parameters (13).

\section{Materials and Methods}

\section{Study Area}

Samples of Hindon water were collected from six different sites of Ghaziabad. Ghaziabad is situated in the middle of Ganga-Yamuna doab about $1.5 \mathrm{~km}$ east of the Hindon river. Geographically, it is located at latitude $28 \circ 40$ $\mathrm{N}$ and longitude $77 \circ 25_{-}$E. The north part of Ghaziabad is bounded by the Meerut district, whereas on the southern part are Gautambudh Nagar and Bulandshahar. The climate of this region is tropical to temperate with extreme temperature conditions in summer (up to $43^{\circ} \mathrm{C}$ ) and winter (up to $3{ }^{\circ} \mathrm{C}$ ). The mean annual rainfall in this region is $702 \mathrm{~mm}$ varying spatially in different sub regions of the district. The river is characterized by sluggish flow throughout year, except during monsoon when rainfall causes a manifold increase in the runoff.

The brief description of sampling station (Figure. 1) is as follows:

1. S-2 (Bhojpur): It is a downstream site of river Hindon and a short stream, i.e. Hindon branch originates at this site.

2. S-3 (Hapur bypass): It is downstream site of Hindon with sever anthropogenic activities, night soil elimination etc.

3. S-4: It is downstream site and located near Murad Nagar.

4. S-5 (Hindon branch): Sample was taken from Hindon branch at a site near Ghazipur landfill. Hindon branch passes through the urban locality of eastern Delhi and ultimately opens into river Yamuna.

6. S-6: It is an upstream sampling site situated near Ataur village.

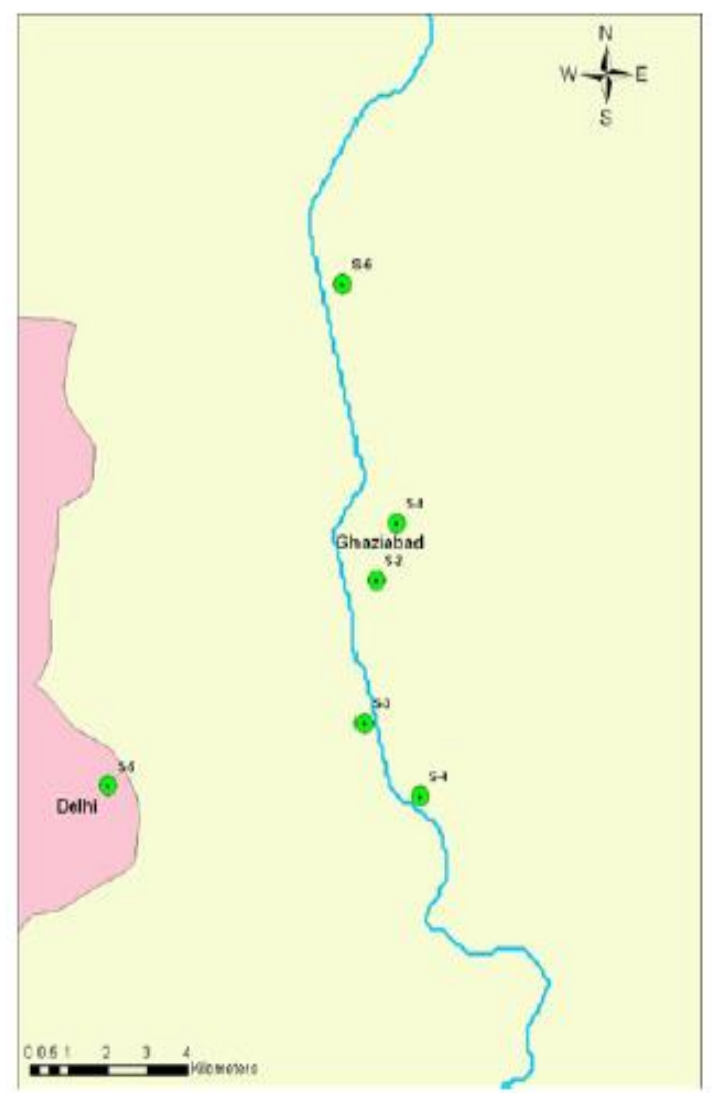

Figure 1. Location map of the sampling sites in Ghaziabad area 
Microbiological and Physicochemical Analysis
Microbiological analysis and a summary of the analytical methods used are described in Table 1.

Table 1 Summary of the microbiological Analysis parameters

\begin{tabular}{|c|c|c|}
\hline Analysis & Method & Sample Volume \\
\hline Escherichia coli & MPN method. Colilert-18/Quanti-Tray 2000 test & $100 \mathrm{ml}$ \\
\hline $\begin{array}{l}\text { Thermotolerant coliform } \\
\text { bacteria }\end{array}$ & $\begin{array}{l}\text { MF, m-FC broth with rosolic acid impregnated on } \\
\text { cellulose pad }\end{array}$ & $100 \mathrm{ml}$ \\
\hline Clostridium perfringens & $\begin{array}{l}\text { Heat treatment at } 70 \pm 2.0^{\circ} \mathrm{C} \text { for } 10 \mathrm{~min} . \mathrm{MF} \\
\text { SFP agar (Becton Dickinson Microbiology }\end{array}$ & $100 \mathrm{ml}$ \\
\hline Campylobacter spp. & $\begin{array}{l}\text { MF, liquid Bolton Campylobacter enrichment } \\
\text { broth, incubation in microaerobic atmosphere at } \\
37 \pm 1.0^{\circ} \mathrm{C} \text { for } 6 \mathrm{~h} \text { followed by further incubation } \\
\text { for } 24 \mathrm{~h} \text { at } 42 \pm 0.5^{\circ} \mathrm{C} \text { after addition of LAB M } \\
\mathrm{X} 131 \text { supplement (LabM), inoculation of } 10 \mu \mathrm{l} \\
\text { onto CCDA agar plates (Oxoid Ltd; Hampshire, } \\
\mathrm{UK} \text { ), incubation microaerobically at } 37 \pm 1.0^{\circ} \mathrm{C} \\
\text { for } 48 \mathrm{~h} \text {. }\end{array}$ & $100 \mathrm{ml}$ \\
\hline Noroviruses & Selective filtration and concentration, RT-PCR & $100 \mathrm{ml}$ \\
\hline $\begin{array}{l}\text { F-RNA } \\
\text { Bacteriophages }\end{array}$ & $\begin{array}{l}\text { Culture of the sample with host strain Salmonella } \\
\text { typhimurium WG49 on semisolid TPGY-based } \\
\text { agar. }\end{array}$ & $1 \mathrm{ml}$ \\
\hline $\begin{array}{l}\text { Giardia spp. and } \\
\text { Cryptosporidium spp. }\end{array}$ & MF, IMS, IFA microscopy and PCR & 101 \\
\hline
\end{tabular}

MPN, most probable number; MF, membrane filtration; SFP, Shahidi Ferguson Perfringens; CCDA, charcoal cefoperazone deoxycholate agar; RT-PCR, reverse transcriptase polymerase chain reaction; TPGY, tryptone-peptoneglucose-yeast extract; IMS, immunomagnetic separation; IFA, immunofluorescence assay (IFA).

\section{Microbiological Analysis}

Microbiological water quality can be estimated by assessing the presence and concentration of faecal pathogen indicator bacteria, for this study Escherichia coli (E. coli) and total coliforms. In general, there are two main techniques to analyze the microbiological water quality: a qualitative and a quantitative method. The qualitative method is trying to know the presence of bacteria in the sample. Common qualitative tests are simple and easy to do. Usually only some ml sample is used and mixed with reagent to show the presence of bacteria in that sample (14). This method is good to do simple water quality monitoring, but not very good to assess the level of contamination in the water. Qualitative method can be used as the first step to analyze the water quality. But afterward, quantitative method can be done if we want to have deeper analysis (15).

There are some presence/absence tests (P/A test) that are familiar in the field. For example: colilert, hydrogen sulphide $(\mathrm{H} 2 \mathrm{~S})$ technique, LMX broth, etc. H2S will give a black colour for positive E. coli presence. LMX broth and colilert will give yellow colour for positive E. coli presence (15). A quantitative method is done by counting the number of live bacteria that are developed on the medium. Live bacteria can be seen from the presence of colonies in the medium after incubation. Colony forming units (CFU) is usually used in scientific word as a term to mention the number of live bacteria. Standard incubation time for E.coli and total coliform bacteria is 24 hours. After incubation, direct plate counting is done with naked eye. This is the reason why the counting of colonies is really depending on the people who count it. A report stated that a replicate that give a value within $30 \%$ of the average still can be accepted or the relative standard deviation is below $15 \%$ (16). For statistical purpose, triplicate of samples is recommended during analysis. Since 
naked eye is used to count the number of bacteria, there is a limitation of bacteria that can be count by naked eye from one plate. Too many bacteria in the plate will make the enumeration of bacteria very difficult. The concentration of the food in the plate will also restrict the bacteria to grow. The bacteria also will compete for space. So nutrient and space can be a limitation for bacteria to grow. Microbiologist use "too numerous to count" (TNTC) to state the number of bacteria cannot be counted by naked eye. There are several ways to write TNTC into a number for quantitative and statistical purpose. One of them is use the number of upper limit of the plate. Upper limit can be defined as the highest accepted value of bacteria that can be grown in the plate (17). But microbiologist also suggested that dilution is a good solution to overcome this problem. So for example, if the $100 \mathrm{ml}$ sample gives TNTC value, we can do 1:10 dilution. Common method that is used for quantitative method is membrane filtration method. This method has some advantages: short period, can assess large sample, and high accuracy (18). But this method cannot be used for turbid sample because it can broke the filter paper and clog the pores.

\section{Statistics Analysis}

Laboratory characteristics of studied water bodies were expressed as mean \pm standard deviation (SD). ANOVA is used to compare data of studies before and after treatment. $P$ value less than 0.05 was considered to be significant correlation and regression analysis were performed for the assessment of improvement in the water quality after treatment.

\section{Result and Discussion}

\section{Microbiological quality of drinking water}

The microbiological test results showed the presence of total coliform and E. coli in $97 \%$ and $71 \%$ of the water samples respectively. Generally, the average total coliform and E. coli density was relatively high in unprotected water sources compared to protected ones.

Table 2 Total coliform and E. coli loads in water samples

\begin{tabular}{|cccccc|}
\hline \multicolumn{2}{|c}{ Water Bodies } & Bhojpur & $\begin{array}{c}\text { Hapur } \\
\text { bypass }\end{array}$ & Murad Nagar & Hindon branch \\
\hline \multicolumn{2}{|c|}{ Parameter tested } & & & & \\
\hline \multirow{2}{*}{ Total } & Minimum & $1.46 \times 10^{2}$ & $1.6 \times 10$ & $\mathbf{0}$ & $\mathbf{8}$ \\
coliforms & $\mathrm{X}$ & $1.51 \times 10^{3}$ & $2.073 \times 10^{2}$ & $1.2747 \times 10^{3}$ & $3.883 \times 10^{2}$ \\
& $\mathrm{SD}$ & $1.102 \times 10^{3}$ & $2.285 \times 10^{2}$ & $1.2567 \times 10^{3}$ & $4.878 \times 10^{2}$ \\
& Maximum & $2.42 \times 10^{3}$ & $6.49 \times 10^{2}$ & $2.420 \times 10^{3}$ & $1.046 \times 10^{3}$ \\
\hline \multirow{2}{*}{ E. coliforms } & Minimum & 0 & 0 & 0 & 0 \\
& $\mathrm{X}$ & $1.22 \times 10^{2}$ & $2.75 \times 10$ & $1.678 \times 10^{2}$ & $1.17 \times 10$ \\
& $\mathrm{SD}$ & $1.21 \times 10^{2}$ & $6.45 \times 10$ & $3.372 \times 10^{2}$ & $1.76 \times 10$ \\
& Maximum & $3.87 \times 10^{2}$ & $2.06 \times 10^{2}$ & $7.70 \times 10^{2}$ & $4.1 \times 10$ \\
\hline
\end{tabular}

Of the four water samples tested, total coliforms were detected in $97 \%$ of the water samples. The number of cfu/100 $\mathrm{ml}$ from all the water sources except one open well exceeded the no risk WHO guidelines of zero $\mathrm{cfu} / 100 \mathrm{ml}$ in drinking water. Wide variations of total coliform were observed within similar water sources but different levels of protection. In samples from unprotected water sources more than $50 \%$ of the water was of high risk by WHO standards. Generally, unprotected springs, open wells, and the open reservoir had more than $50 \%$ of their sources with more than $300 \mathrm{cfu} / 100 \mathrm{ml}$ counts than those from protected sources.
The correlation between total coliform and E. coli counts was positive and significant $(r=$ 0. 817, $\mathrm{p}<0.05)$. Total coliform counts were significantly $(\mathrm{p}<0.05)$ higher than those of E.coli. The general trend was that while densities of $E$. coli were lower than those of total coliform for all the water sources, the trend in the number of cfu of $E$. coli increasing as those of total coliforms increased was observed to be significant.

The presence of coliforms in drinking water is enough grounds for assuming that a potential health hazard existed because of the possible presence of pathogens 1 . The results of this study 
reveal that average bacterial density in drinking water was relatively high, especially from unprotected water sources, compared with that from protected sources. The presence of E. coli in water suggests enteric pathogens and faecal pollution and has been reported to be the causative agent of diarrhoea, urinary tract infection, haemorrhagic colitis, and haemolytic uraemia syndrome in similar studies elsewhere.

The number of total coliform and E. coli counts found in unprotected water sources suggest though not conclusively that poor source water protection and poor sanitation conditions and practices are potential reasons for the high presence of microbiological contaminants. The big difference in the microbial counts from water samples of similar protection status might be indicative of widely varying hygiene behaviours in the households. This assertion is supported by the cleaning behaviours and habits of the household members at or near the water sources. Some washed their laundry close to water sources while others used dirty containers to collect water from the source. Contamination of water was also potentially tied to livestock and human faeces that created a diffuse source of faecal contamination to water sources, poor hygiene and sanitation practices that include laundry activities close to water sources by households; and water sources being very near or down slope of latrines. This implied the risk of contamination was very high. In a few cases there was a decrease in the numbers of total coliforms and E. coli. This was linked to the protection of the water sources and hygiene practices by the household members using the sources. Based on these findings, it is prudent to recognize the link between water quality, environmental quality, sanitation and public health. These observations suggest the need for focused interventions on source water protection and sanitation practices as this could lead to improvements in water quality at source.

\section{Conclusion}

After the field observation and water quality test, it can be concluded that water is contaminated with faecal contaminants where as other chemical contaminants such as ammonia, $\mathrm{pH}$, nitrate etc. are not at risk level. Residents of Chotidanda are susceptible for the sickness caused by faecal pathogens. Similarly, hand hygiene tests gave out the positive result. More than $50 \%$ of the hand samples contained E.coli. The pathogen transmitted either through the contact with contaminated water or because of the poor hygiene. It can be assumed that, water has been contaminated because of the poor personal hygiene. The other reasons for water contamination are leakages in water supply pipelines and forests and households animals which are not kept in safe place.

\section{Acknowledgement}

The authors are thankful to IJIST Journal for publishing their article.

\section{Conflicts of Interest}

The author declares that there are no conflicts of interest.

\section{References}

1. Asadi SS, Padmaja V and Reddi M Anji. Remote sensing and GIS techniques for evaluation of ground water quality in Municipal Corporation of Hyderabad (Zone 5), India. Int. J. Env. Res. Public Health. 2007; 4(1): 45-52.

2. George I., Anzil A, Servais P. Quantification of fecal coliform inputs to aquatic systems through soil leaching. Water Res. 2004; 38, 611-18.

3. Curtis V and Cairncross S. Effect of washing hands with soap on diarrhoea risk in the community: a systematic review. Infect Dis. 2003; 3:275-81.

4. Dhakad NK and Chaudhary P. Hydro biological study of Natnagra pond in Dhar district (M.P.) with special reference to water quality impact on potability, irrigation and aquaculture. Nature Env. Polln. 2005; Techno 4(2): 269-72.

5. Elder GH, Hunter, PR and Codd GA. Hazardous freshwater cyanobacteria (blue green algae). Lancet 1997; 341:1519-20.

6. Dechesne M, Soyeux E, Loret JF, Westrell T, Stenström TA, Gornik V, Koch C, Exner M, Stanger $\mathrm{M}$, Agutter $\mathrm{P}$ et al. Pathogens in Source Water, Microbiological Risk Assessment: A Scientific Basis for Managing Drinking Water Safety from Source to Tap; Microrisk European Project: Nieuwegein, The Netherlands. 2006; pp. 1-42.

7. Murugesan S, Dhamodhar KS and Chandrika D. Comparative study of ground water sources from central to western region of Chennai, India. Nature Env Polln Techno. 2005; 4(1): 87-91.

8. Delbec M, Chesnot T, Mignard C, Duchemin J. Risques Microbiologiques Emergents Pour la Ressource en Eau, Cas de L'agglomération Parisienne. In Proceeding of Second National Congress Société Française Santé Environnement (SFSE): Paris, France; 14-15 Dec 2011.

9. Ferguson C, Husman AMD, Altavilla N, Deere D, Ashbolt N. Fate and transport of surface water 
pathogens in watersheds. Crit. Rev. Environ. Sci. Technol. 2003; 33, 299-361.

10. Mishra NK and Sahoo HK. Evaluation of groundwater quality in the around Deogarh. Indian Journal Environmental Protection. 2003; 23(6): 667-72.

11. Curriero FC, Patz JA, Rose JB, Lele S. The association between extreme precipitation and waterborne disease outbreaks in the United States, 1948-1994. Am. J. Public Health. 2001; 91, 1194-99.

12. Murhekar Gopalkrishna H. Determination of physicochemical parameters of surface water samples in and around Akot City., International Journal of Research in Chemistry and Environment. 2011; 1(2): 183-7.

13. Murphy T P, Irvine K, Guo J, Davies J, Murkin H, Charlton $\mathrm{M}$ and Watson SB. New Mycrocystin concerns in the Lower Great Lakes, Water Qual. Res. J. Canada. 2003; 38 (1):127-140

14. Naden PS, Old GH, Eliot-Laize C, Granger SJ, Hawkins JMB, Bol R, Haygarth P. Assessment of natural fluorescence as a tracer of diffuse agricultural pollution from slurry spreading in intensively-farmed grasslands. Water Res. 2010; 44, 1701-12.

15. Datta $M$ and Jayshree S. Fundamentals of fresh water Biology. Narendra publishing House, Delhi (India). 1995; pp. 1-222.

16. Edge TA, Hill S, Seto P, Marasalek J. Librarydependent and library-independent microbial source tracking to identify spatial variation in faecal contamination sources along a lake Ontario beach (Ontario, Canada). Water Sci. Technol. 2010; 62, 71927.

17. Muirhead RW, Collins RP, Bremer PJ. Interaction of Escherichia coli and soil particles in runoff. Appl. Environ. Microbiol. 2006; 72, 3406-11.

18. Esrey SA, Potash JB, Roberts L and Shiff C. Effects of improved water supply and sanitation on ascariasis, diarrhoea, dracunculiasis, hookworm infection, schistosomiasis, and trachoma. World Health Organisation. 2009; 69:609-21. 